\title{
AS VÁRZEAS URBANAS DE SÃO PAULO: Estudo do processo de ocupação e transformação das várzeas dos rios Tietê, Pinheiros e Tamanduateí
}

\author{
Anita Rodrigues Freire e Regina Maria Prosperi Meyer \\ Universidade ou instituição a qual pertence: Universidade de São Paulo - Programa de pós-graduação da \\ Faculdade de Arquitetura e Urbanismo \\ Orientador da pesquisa: Regina Maria Prosperi Meyer \\ anitafreire@gmail.br
}

\section{RESUMO}

O principal problema que este projeto de pesquisa busca examinar é: O que caracteriza o processo de transformação das várzeas urbanas de São Paulo? O objeto de pesquisa proposto são as várzeas urbanas dos três principais rios que cortam a cidade de São Paulo: Tietê, Pinheiros e Tamanduateí. Pretende-se realizar a caracterização da área de estudo por meio de produção e análise cartográfica. A leitura das diferenças e similaridades entre as várzeas urbanas é de fundamental importância para a problematização e avaliação do potencial de ocupação futura das áreas estudadas. Também faz parte desta pesquisa a análise de alguns projetos de arquitetura e urbanismo elaborados em áreas de várzea. A partir destes estudos acredita-se ser possível chegar a uma análise e avaliação do potencial de urbanização das várzeas dos principais rios de São Paulo, possibilitando a discussão e os encaminhamentos dos novos processos de transformação, já em andamento, destas áreas.

Palavras chave: várzea urbana, São Paulo, potencial de projeto urbano e urbanismo.

\begin{abstract}
The main problem that this research project examines is: What characterizes the process of transformation of the urban floodplains of São Paulo? The proposed research object is the urban floodplains of the three main rivers of city of São Paulo: Tietê, Pinheiros and Tamanduateí. It is intended characterize the study area through cartographic production and analysis. The reading of the differences and similarities between the urban floodplains is important for the problematization and evaluation of the occupation potential of the studied areas. Also part of this research is the analysis of some architectural and urban planning projects elaborated in a floodplain area. From these studies, it is believed that it is possible to reach an analysis and evaluation of the potential for urbanization of the floodplains of São Paulo's main rivers, enabling discussion and referrals of the new transformation processes that is already happening in these areas.
\end{abstract}

Key words: Urban Floodplains, São Paulo, Potential of urban design and urbanism 
O objetivo geral desta pesquisa é caracterizar e analisar o processo de ocupação das áreas de várzeas dos rios Pinheiros, Tietê e Tamanduateí, tanto na sua dimensão histórica como a atual transformação e destinação de seus novos usos.

O principal problema que este projeto busca examinar é: O que caracteriza (atributos físicos e funcionais) o processo de transformação das várzeas urbanas de São Paulo?

Define-se por processo de transformação o mecanismo pelo qual o tecido urbano se modifica, passando por alterações relacionadas ao uso, à ocupação espacial e à morfologia urbana.

Define-se como várzeas urbanas as áreas situadas dentro do perímetro urbano, localizadas às margens dos três principais rios de São Paulo (Tietê, Pinheiros e Tamanduateí), localizadas abaixo da cota 730.

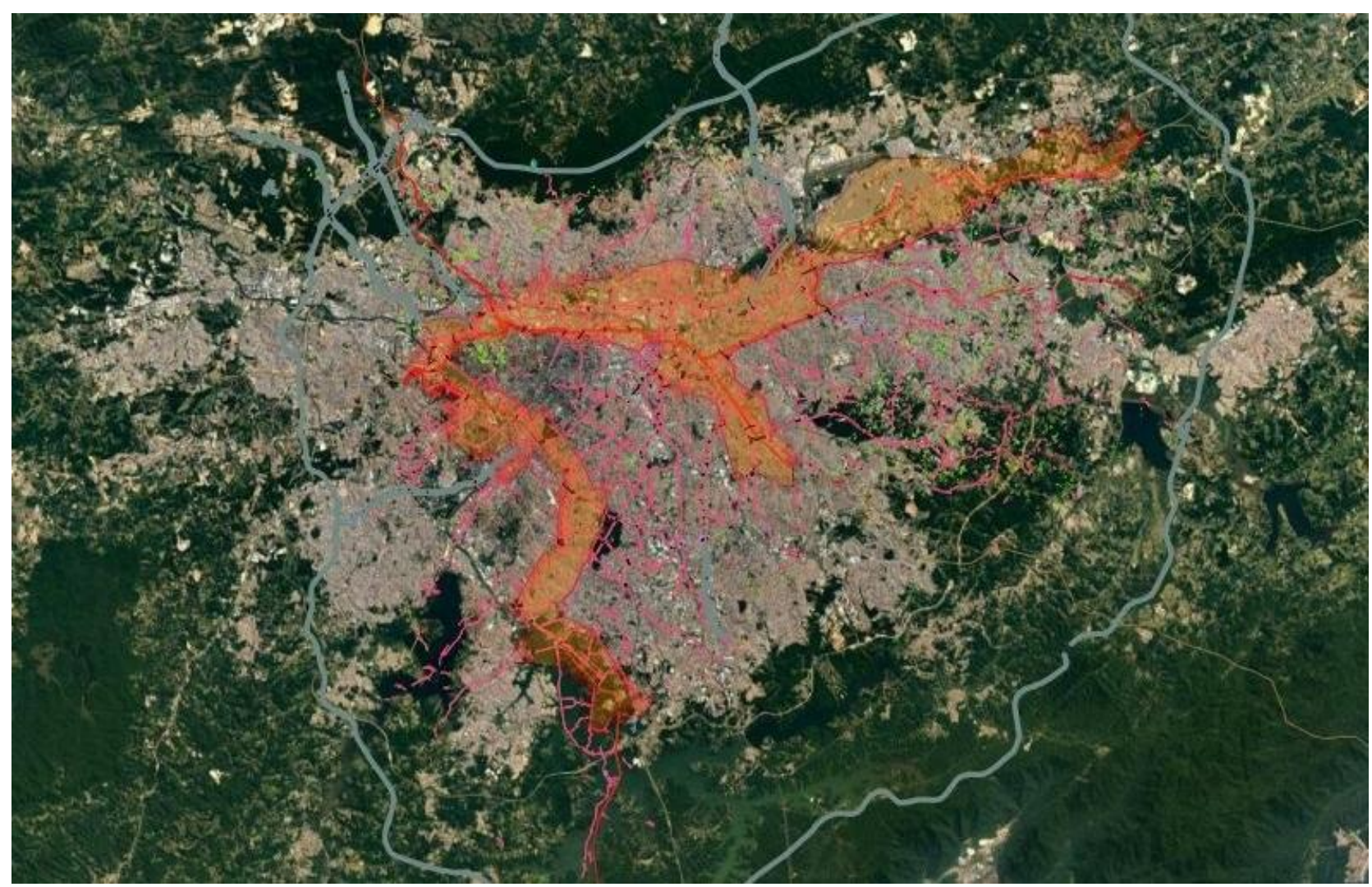

Figura 1. Recorte de pesquisa a partir dos critérios elencados pela autora.

Elaboração própria a partir de bases fornecidas pela PMSP, disponibilizado no site Geosampa.

A cota 730 é uma cota recorrente na literatura para a definição das áreas de várzea. A'bsaber (2007), Seabra (1987) e Franco (2005) a adotam como referência. Ela marca o fim da planície aluvial, incorporando além do leito maior do rio, os terraços fluviais.

Sobre a definição da planície aluvial: "A planície aluvial corresponde à feição geral que abarca toda a formação sedimentar de origem aluvionar, e que contém registros de toda sua história geológica. Os terraços, por exemplo, são testemunhos de antigos níveis mais altos preteritamente ocupados pelos sedimentos aluvionares, posteriormente retrabalhados pela erosão fluvial. A planície de inundação corresponde a toda a extensão mais baixa da bacia que se estende das margens do rio até os terraços. A calha corresponde ao canal ocupado pelas águas regulares do rio ao longo do ano. (...), caso se queira adotar o termo várzea como sinônimo de toda planície de inundação, há de se considerar que essa várzea é constituída de segmentos com diferentes características, comportamentos e funções." (Santos, 2017:83) 


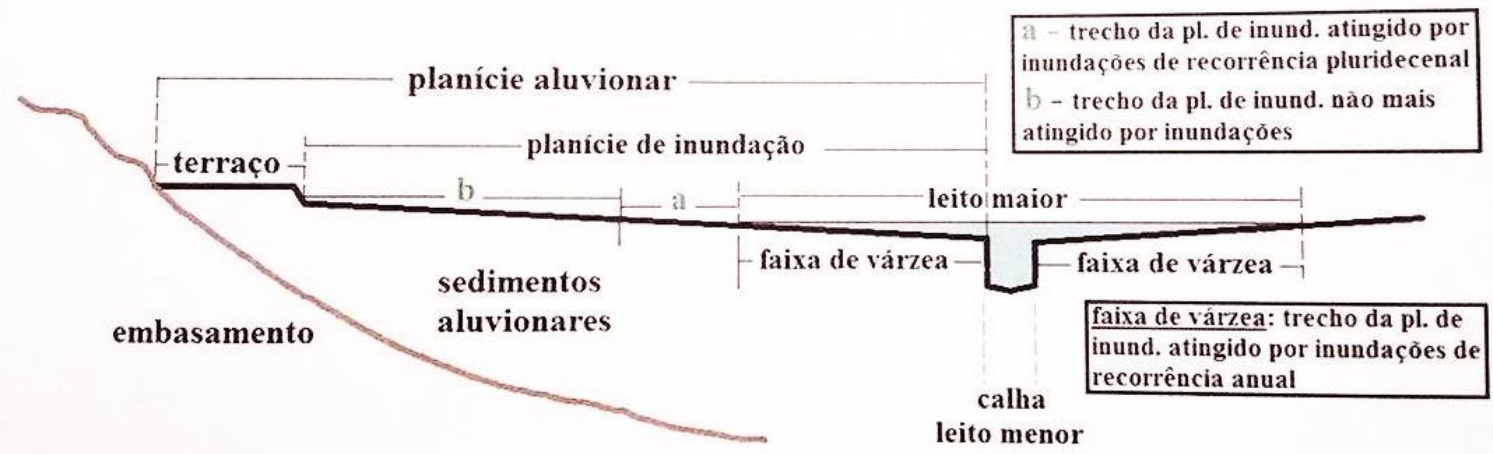

Figura 2. Seção hidromorfológica típica de uma bacia aluvial fluvial com rio de baixa declividade- como no caso de São Paulo Fonte: (Santos, 2017:81)

A principal hipótese para a questão apresentada é que apesar das muitas diferenças entre cada uma das várzeas analisadas, o que as caracterizam são as semelhanças em seu processo de ocupação (ocupações setorizadas, com grandes glebas, áreas com baixa densidade construtivas e baixa densidade habitacional, infraestrutura urbana incompleta), o que faz com que se apresentem ainda hoje como principais áreas potenciais de transformação da cidade a partir de novas premissas de ocupação e uso do solo no seu nível intraurbano.

Trata-se de pesquisa de natureza descritiva e exploratória a ser realizada por meio de elaboração de bases cartográficas com ênfase em dados geomorfológicos, de infraestrutura e de uso e ocupação do solo, que possibilitem a análise do processo de ocupação e caracterização das áreas do recorte.

A revisão bibliográfica possui duas vertentes: uma primeira que busca processos históricos e parâmetros de análise de várzeas urbanas; e uma segunda, que deverá se debruçar sobre partidos de projeto e obras que abordem o tema da recuperação urbana das várzeas.

Para a caracterização das áreas das várzeas urbanas de São Paulo, foram levantadas, analisadas e produzidas bases cartográficas georeferenciadas indicando as formas de ocupação e infraestruturas destas áreas. Para elaboração das bases cartográficas, foram utilizadas as bases disponibilizadas pela Prefeitura Municipal de São Paulo (Geosampa, Mapa Digital de Cidade, Plano Diretor Estratégico e Carta Geográfica), Instituto Brasileiro de geografia e Centro de Estudos da Metrópole.

\section{JUSTIFICATIVA}

O interesse pela pesquisa surgiu da possibilidade de discussão do processo de ocupação das áreas de várzeas a partir de suas recentes transformações, reiteradas pela atualização dos instrumentos de planejamento urbano da cidade de São Paulo, principalmente o Plano Diretor Estratégico - PDE (2014) e a Lei de Uso e Ocupação do Solo - LUOS (2016) que delimitaram como área de transformação metropolitana área que coincide com as várzeas urbanas dos principais rios da cidade de São Paulo.

As áreas de várzea se revelaram como elementos de grande importância na construção da cidade de São Paulo e na sua estruturação enquanto metrópole, pois configuram sistemas territoriais que vão além do perímetro urbano do Município de São Paulo. Possuem escala metropolitana e regional.

O processo de consolidação de São Paulo enquanto metrópole, ao longo das três primeiras décadas do século XX, muito se deve à transformação da cidade possibilitada pela reestruturação dos eixos de mobilidade e pelo processo de renovação das áreas de várzea. Hoje as várzeas continuam sendo peça chave para a transformação urbana da cidade: "A escala dos espaços subutilizados das instalações fabris e, sobretudo, o potencial da infraestrutura ferroviária obsoleta, ambos articulados entre si e em relação às demais infraestruturas implantadas sobre as várzeas, são os principais elementos preexistentes, a partir dos quais pode-se pensar ações indutoras de transformação. Isto porque a importância crescente do padrão de mobilidade, como condição da cidade contemporânea e a demanda por novas áreas disponíveis para processos de urbanização, (...) apontam, mais uma vez, para a condição estratégica das várzeas" (Franco, 2005:208).

A potencialidade de transformação urbana das áreas de várzea reside no fato de muitos trechos não terem sido objeto de urbanização completa, possuindo oferta de espaços livres ou possíveis de transformação; de 
muitas áreas estarem em processo de mudança de uso (áreas industriais em transformação), e na possibilidade de associação do desenvolvimento com o sistema de mobilidade (todas as linhas da Companhia Paulista de Trens Metropolitanos - CPTM situam-se nas várzeas paralelas ao rios, algumas linhas de metrô estão previstas para cruzarem as áreas de várzea).

Segundo Sales (2008), a cidade contemporânea se expõe, isto é, testa sua hipótese, pelos territórios de intermediação, ${ }^{1}$ entre os quais podemos localizar as áreas que passam: i) por processo de obsolescência e desativação; ii) pela dissolução de valores posicionais (mudança de uso); e iii) pelas transformações vinculadas a novos sistemas técnicos (grandes infraestruturas). O que nos leva a concluir que a várzea hoje pode-se constituir em um território de intermediação de grande relevância na metrópole de SP. Principalmente levando em consideração o esgotamento dos terrenos para novas construções no município: "Não há mais espaço para a ampliação difusa da metrópole: é preciso promover o crescimento da cidade para dentro de suas estruturas consolidadas, adensando as áreas onde há pouca oferta habitacional e grande oferta de empregos. O território de estruturação metropolitana é estratégico para enfrentar esse desafio" (Franco et al., 2015:59).

A existência de áreas passíveis de mudanças distribuídas ao longo de um eixo estruturante abre diversas possibilidades de intervenção: desde a elaboração de diretrizes de ocupação daquelas áreas, até a proposição de projetos estruturadores articulados em rede.

A pesquisa faz-se oportuna na medida em que as recentes atualizações dos instrumentos de planejamento da Prefeitura Municipal de São Paulo - PMSP (2015) atribui grande importância às áreas de várzea. A zona denominada de Macro Estruturação Metropolitana- MEM, tem sua área de abrangência delimitada da seguinte forma "A Macroárea de Estruturação Metropolitana abrange áreas das planícies fluviais dos rios Tietê, Pinheiros e Tamanduateí, com articulação com o Centro e prolongamento junto às avenidas JacuPêssego, Cupecê e Raimundo Pereira de Magalhães e das rodovias Anhanguera e Fernão Dias e caracteriza-se pela existência de vias estruturais, sistema ferroviário e rodovias" (Prefeitura Municipal de São Paulo, 2014:45).

A MEM, delimitada pelo PDE, apropria-se das áreas de várzea direcionando planos, projetos, adensamentos e transformações a estas áreas. Portanto a compreensão da consolidação destas áreas na estruturação da metrópole se faz de grande importância.

\footnotetext{
1 Sobre o conceito de território de intermediação usado pela autora: "Aqui se pretende abordar esta figura, denominada 'território de intermediação', como 'zona de contaminação', como conceito que articula espaço e programa (Tschumi) e que, por encontrar-se na bordas ou nas margens entre dois territórios, já aponta possibilidades de atualização e de expressão das diferentes espacialidades e temporalidades da cidade contemporânea" (Sales, 2008:26).
} 


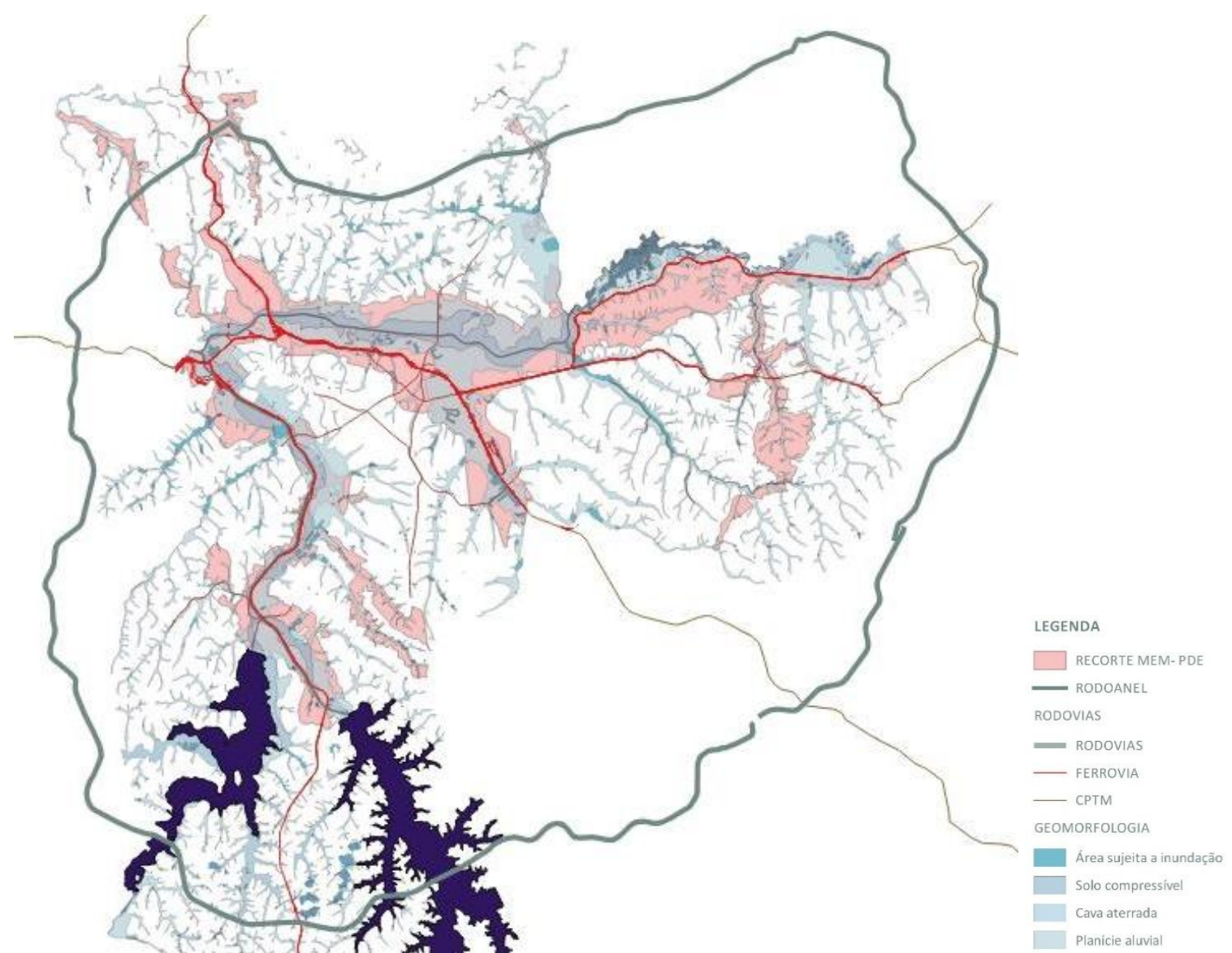

Figura 3: Rede de transporte sobre trilhos com sobreposição das planícies aluviais (azul) e área da MEM- PDE (rosa). Elaboração própria a partir de dados fornecidos pela PMSP.

\section{O PROCESSO HISTÓRICO DE OCUPAÇÃO DAS ÁREAS DE VÁRZEA}

\subsection{A associação entre o sistema de mobilidade e hidrorafia}

A associação entre hidrografia e infraestrutura na cidade de São Paulo teve início na época colonial e esteve intimamente associada ao seu desenvolvimento econômico e produtivo (Franco, 2005). A leitura do estabelecimento dos aglomerados urbanos associado à hidrografia teve origem no domínio sobre os caminhos, onde o transporte fluvial podia ser considerado como o principal instrumento de colonização: "Os rios Tietê e Tamanduateí foram muito importantes durante o período de colonização brasileira, pois por meio deles iniciou-se a exploração do interior brasileiro, por parte das tropas conduzidas por bandeirantes" (Brocaneli et al., 2008:148). A navegação pelo rio Tietê possibilitou a exploração do interior do Brasil, ampliando a área de exploração da colonização portuguesa em direção às terras de Paraná e Cuiabá (Gorski, 2010).

A determinação da escolha do sítio para implantação do núcleo urbano em função da hidrografia deve-se não só pelo importante papel do rio como estratégia de proteção em relação a possíveis invasores, mas também pelo apoio às atividades básicas de funcionamento e manutenção dos núcleos, e ainda pela possibilidade de sua utilização como um sistema de caminhos e, portanto, principal elo de comunicação entre as diversas aglomerações dispostas no território. "Desde os primórdios da aldeia jesuítica primitiva, a presença de boas águas orientou a escolha de locais de assentamentos de colonização, principal aspecto da ocupação pelo menos nos dois primeiros séculos da formação da vila paulistana (...). Os rios e a própria várzea como paisagem seriam, desde a fundação, fatores estruturadores da organização da vila, assentada sobre as colinas, cercada pelos campos e várzeas, localização geograficamente encravada entre a Serra do Mar e as possíveis descobertas e possessões do interior, servida pelo longo rio Tietê e seus afluentes, referenciais para transporte e comunicações" (Kahtouni, 2004:13). No território colonial, eram os leitos de água que estruturavam o território. 
A presença de núcleos urbanos localizados próximo aos rios, que estruturavam os caminhos coloniais, foi um padrão de urbanização e uma condição essencial no processo de colonização no Brasil: "Tão logo puderam perceber essa condição estratégica, os colonos trilharam os passos da colonização sobre a vasta rede de caminhos fluviais em torno do Tietê bem como sobre os caminhos terrestres conectados à trilha Peabiru, há muito utilizados pelos indígenas" (Franco, 2005:29).

Mesmo com a mudança no padrão de deslocamentos, quando o sistema fluvial deixou de ser o principal meio de transporte, os rios mantiveram-se como importantes eixos organizadores do território, pois os caminhos ainda se estabeleciam dentro de sua área de abrangência, muito pela vantagem fornecida pela condição do relevo de seu entorno. Ao longo dos caminhos de água, vieram a se estabelecer as primeiras estradas (Gorski, 2010).

Apesar da complexa relação de dependência da cidade com seus rios, estes viabilizaram sua fundação e permitiram tanto o seu abastecimento como sua estruturação e interconexão com o território, o seu desenvolvimento ocorreu sempre de modo a lhe voltar as costas, ou seja, o rio sempre foi considerado fundo, e nunca compôs a frente da cidade.

E mesmo com os rios e suas várzeas tendo um papel fundamental na constituição das cidades, durante muito tempo o crescimento das cidades se orientou em direção às terras mais secas (Ab'saber, 2007). Essa lógica de ocupação se deve, em grande parte, ao medo da população da cidade em relação às inundações e às questões de salubridade.

Posteriormente, ao longo das áreas da várzea foram implantadas as ferrovias, e estas áreas passaram a concentrar as infraestruturas de mobilidade: "As várzeas e planícies fluviais eram as únicas parcelas do terreno cujas características geomorfológicas poderiam atender às demandas técnicas e financeiras por amplos raios de curva, baixa declividade, grande extensão de áreas disponíveis e baratas para a construção dos elementos pertencentes ao sistema, vias, pátios, estações e armazéns. Por isto, ao passar pela Bacia de São Paulo, o sistema ferroviário fomentou um ciclo de investimentos em larga escala sobre essas áreas. No caso de um território de planalto como o da Bacia de São Paulo, caracterizado por uma topografia recortada e irregular, as características técnicas do sistema ferroviário sugerem que os fluxos viários sejam associados aos caminhos traçados pelas águas" (Franco, 2005:104).

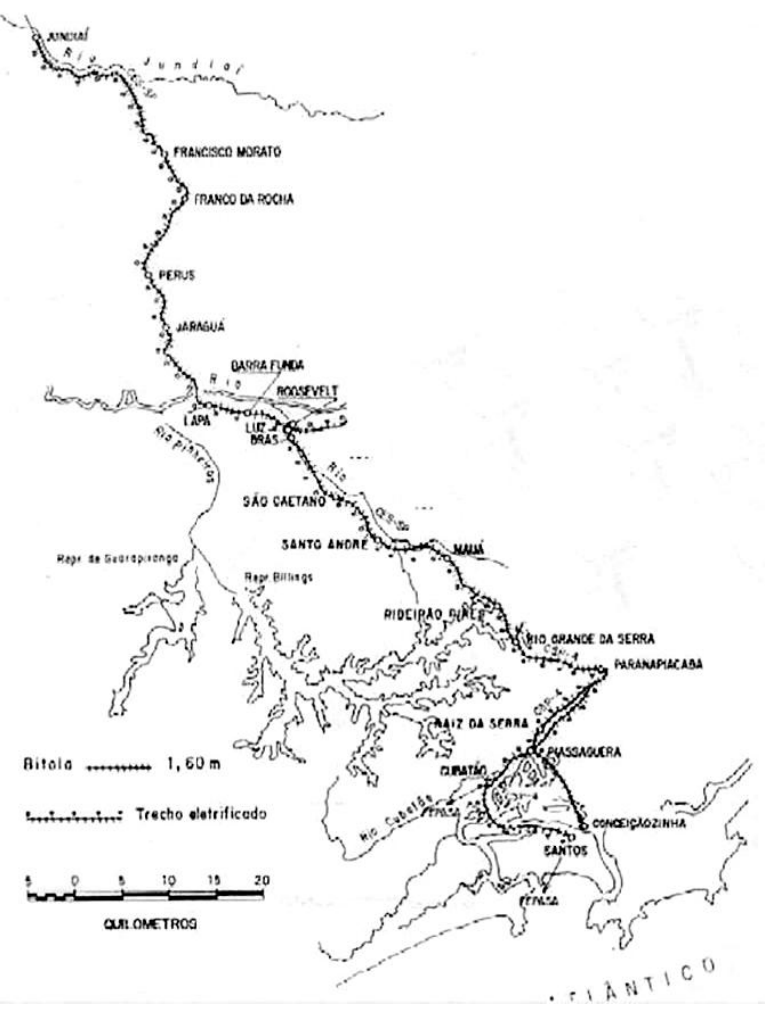

A primeira linha férrea foi a Santos-Jundiaí, implantada em 1865, paralela ao curso do rio Tamanduateí, Tietê e Jundiaí.

Figura 4: Mapa Ferrovia Santos Jundiaí: hidrografia e linha férrea. Fonte: (Franco, 2005:84)

Cada um dos sistemas de mobilidade implantados a partir do eixo hidrográfico da cidade de São Paulo correspondeu a uma etapa do sistema de produção. Enquanto o sistema de transporte hidroviário estava vinculado às entradas e bandeiras que organizavam as transações comerciais no território colonial, o sistema de transporte ferroviário se vinculava à produção da economia cafeeira, que usava a ferrovia para escoar a produção do interior do estado de São Paulo para o porto de Santos. Já o sistema de transporte viário foi o responsável por viabilizar a nova lógica de produção capitalista, na qual a possibilidade de transitar rapidamente no território é o que valoriza o espaço e faz com que o território atraia os meios de produção.

Assim que foram sendo concretizadas, as avenidas marginais tornaram-se os principais eixos de acesso à cidade, ligando as principais rodovias, substituíram o transporte sobre trilhos na escoação da produção. As 
margens dos rios foram ocupadas o máximo possível com a ampliação da área dedicada aos leitos de carros das avenidas marginais: "Com base na política rodoviarista, a partir da década de 60 do século XX, os usos das margens do rio, espontâneos ou induzidos deram-se não mais em função do curso d'água, mas em função das avenidas construídas ao longo dele. A lógica do escoamento da produção agrícola e do abastecimento da cidade passava pela facilidade de acesso às rodovias estaduais e federais, propiciando usos ligados a essas atividades, como Indústrias, galpões de armazenamento e pátios de transportadoras" (Nunes, 2004:110).

Ainda que sua importância enquanto concentradora dos eixos de mobilidade tenha se mantido com a associação dos rios aos eixos rodoviários, a área de várzea passou a ser apenas lugar de passagem, nunca lugar de estar. As vias de circulação expressas permitem o fácil deslocamento de pessoas e mercadorias, mas também funcionam como barreira, fragmentando o território urbano pelos mínimos pontos de transposição, que quase sempre priorizam o carro.

\subsection{0 processo de industrialização e a valorização das várzeas}

Por concentrarem diversas infraestruturas as áreas de várzea passaram por um processo de valorização: "A incorporação das infraestruturas viabiliza, ampara e impulsiona o uso do território em escala compatível com sua dimensão, a partir do momento em que torna disponíveis os meios de deslocamento, de acesso aos lugares, de abastecimento, de obtenção de energia, de comunicação etc." (Franco, 2005:16).

Disponibilizando grandes porções de terras planas e baratas, com a chegada da ferrovia, as várzeas permitiram a instalação do primeiro parque industrial. Ela viabilizou o transporte de mercadorias, insumos, sobretudo a água, além da mão de obra que começava a habitar no entorno, criando os primeiros bairros populares e operários. "(...) a implantação das ferrovias, desde o último quartel do século passado, valorizava determinados trechos da várzea no trecho paulistano, para outros fins. Como uma modalidade de transportes adequado e eficiente para época, criou nas estações que foram se estabelecendo no trecho paulistano, locais apropriados às implantações industriais, ao estabelecimento de armazéns de depósitos... e como desdobramento lógico, valoriza terrenos adjacentes por vezes em plena várzea, como foi o caso da Lapa, da Barra Funda e da Água Branca." (Seabra, 1987:78)

As indústrias implantaram-se preferencialmente ao longo da ferrovia: "Se um terreno inundável não estivesse atrelado a atividades extrativistas, era considerado inútil e transformava-se em meio para atividades do setor industrial, como terreno extremamente barato e conectado à ferrovia" (Kahtouni, 2004:90).

É importante ressaltar que houve diferenças no processo de implantação industrial ao longo das várzeas. Enquanto as várzeas no rio Tietê (Lapa de Baixo, Barra Funda e Bom retiro) e no rio Tamanduateí (Mooca, Brás e Pari) as várzeas tiveram uma ocupação predominantemente industrial no rio Pinheiros não apresentou tal caráter. O processo de canalização e drenagem, empreendido pela Cia. Ligth and Power, tornou suas terras caras demais para implantação de indústrias. Ainda assim, houve exceção: o distrito industrial do Jaguaré, empreendido por Dumont Vilares, e o distrito industrial de Jurubatuba, empreendido por Francisco Matarazzo. (Seabra,1987).

A Figura 5 ilustra a setorização das indústrias nas áreas de várzea. 
1930

1950

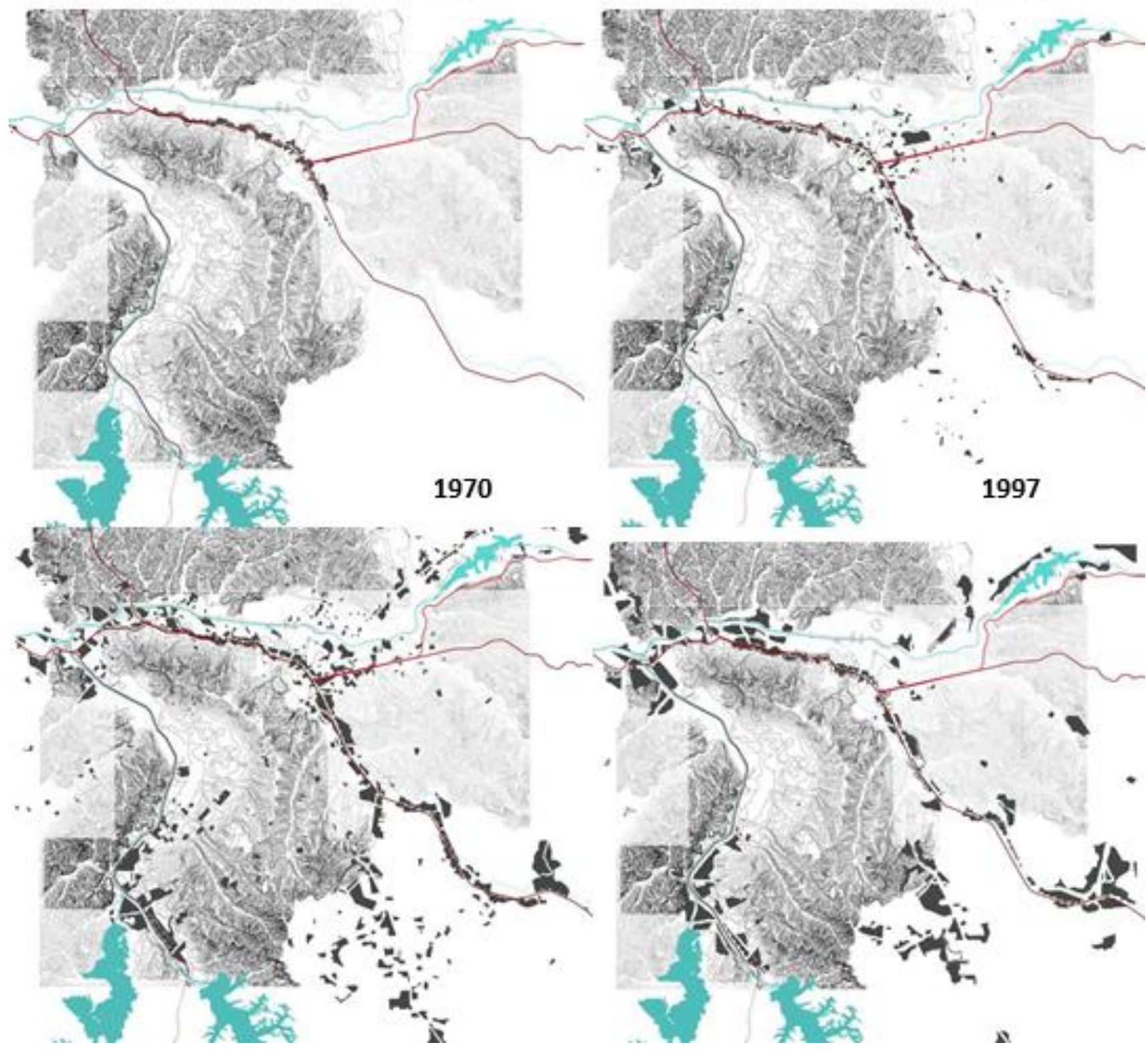

Figura 5: Indústrias (mancha preta) ao longo das várzeas e linha férrea (linha vermelha).

Elaboração própria a partir de dados do LUME- Laboratório de Urbanismo da Metrópole (MEYER et al., 2004).

A várzea foi utilizada como função da cidade, pois concentrou tanto a infraestrutura (vias, ferrovias, estações, dutos) como os meios de produção (indústrias e bairros operários). Tornou-se um território especializado e, consequentemente sujeito às transformações sucessivas vividas pela própria evolução do sistema produtivo. A concentração industrial possibilitou a produção econômica que, por sua vez, permitiu a própria construção do meio urbano, ou seja, as várzeas definiram a base material, territorial e espacial para o desenvolvimento da própria cidade (Franco, 2005).

Esse processo de incorporação das áreas de várzea ao meio urbano desencadeou grandes transformações nas relações existentes em seu território: "É também, como lugar de uma forma particular de trabalho que as várzeas começaram ser integradas à totalidade que se forma a partir da cidade. Estabeleceu-se uma divisão do trabalho que tem neste caso uma dimensão territorial muito nítida, e que se explica a nosso juízo, pelas características essenciais das várzeas mesmo. Disto deriva a conclusão: antes que pudesse aparecer materialmente a cidade nas várzeas, as várzeas existem em função da cidade, para a cidade. Ao mesmo tempo que as várzeas começaram a ser circundadas pela cidade, processo que as redefinia para usos urbanos potenciais, elas já existem em função da cidade" (Seabra, 1987:77) 


\subsection{O processo de retificação e apropriação das áreas de várzea}

A canalização e retificação dos rios de São Paulo foram realizados em épocas, e por atores sociais e interesses muito diferentes. A canalização do rio Tamanduateí, foi promovida pela prefeitura, no período de 1849 a 1916; a canalização do rio Pinheiros foi promovida pela Companhia The São Paulo Tramway Light and Power Company Limited entre 1927 e a década de 60. A canalização do rio Tietê, foi promovida pela prefeitura, seus primeiros projetos datam do final do século XIX, com as obras se efetivando no período entre 1937 até os anos 60.

As canalizações foram implementadas por grandes obras de engenharia, que buscavam resolver a questão sob um ponto de vista absolutamente técnico: traçar o menor percurso de modo a garantir declividade e velocidade necessárias para que não se provocasse erosão em nenhum trecho (Seabra, 1987). Em nenhum momento, foi incorporado ao processo as relações naturais e paisagísticas associadas às várzeas.

O discurso que exigia e justificava o processo de canalização se diferenciava entre elas: enquanto no rio Tietê e Tamanduateí as justificativas giravam em torno da questão do saneamento e controle de enchentes; no rio Pinheiros justificava-se pela viabilização do complexo energético. $E$, embora todas essas razões fossem até certo pontos reais e justificáveis, é importante entender que as obras de retificação, canalização e drenagem das várzeas fazem parte de um amplo processo de produção de terra urbana e incorporação das áreas de várzea à cidade.)

As várzeas foram incorporadas, mas tiveram um processo de urbanificação bastante incompleto. Sobre o conceito de urbanificação: "O termo urbanificação designa a ação de dotar o território de um conjunto de redes técnicas necessárias para a instalação da vida urbana. Corresponde à dimensão material do processo de urbanização, na medida em que prepara o território não-urbanizado para desempenhar plenamente suas funções urbanas. O conceito de urbanificação deficiente designa justamente a contradição dos processos de urbanização que se instalam sem contar com as redes técnicas mais essenciais para o desenvolvimento da vida material e social das comunidades" (Meyer et al., 2004:159).

Seabra (1987) revela que o processo de apropriação das várzeas dos rios Tietê e Pinheiros, apresentaram diferenças cruciais: "Trato em separado, a retificação do Tietê e a retificação do Pinheiros devido a circunstâncias muito particulares que as definiram. $O$ processo que se desenvolveu num e noutro vaso mostrou que, no Tietê, tinha lugar um processo clássico de investimento público profundamente mediatizado por interesses privados, enquanto o estudo do Pinheiros revelou estratégias de valorização articuladas no interior de um monopólio, constituído sob a proteção do Instituto Jurídico da Concessão e sob a égide de um grande truste do século XIX, o Grupo Light. Consequentemente, o processo em si mesmo seria fundamentalmente diferenciado pois que, não há leis e regras a atuar no interior do monopólio. Este tem suas próprias leis e, nesse sentido, representa sempre uma super-imposição, uma descontinuidade histórica do ponto de vista de vida, das formas de produzir e reproduzir-se a sociedade onde ele se instala." (Seabra, 1987:23)

O processo de canalização do rio Tietê teve diferentes objetivos ao longo do tempo, sanear, regularizar a vazão, resolver os problemas das inundações e por fim urbanizar e permitir a incorporação das áreas de terras pela cidade. Teve também como objetivo estabelecer um sistema eficiente de circulação na cidade, possibilitando o estabelecimento de indústrias e meios de produção metropolitanos. O processo de valorização das terras foi um ganho para os proprietários de terras ribeirinhos e também pelo poder público, que por ter realizado o processo de canalização, se tornou proprietário de grande parte das terras das várzeas do Tietê: "A Prefeitura Municipal, adotou o critério de desapropriar com fins de utilidade pública apenas as terras necessárias à alocação do canal, e fez prevalecer o que estabelecera o Código das Águas em 1934; tornava-se proprietária do leito antigo. As pendências com a as propriedades particulares para as quais propôs em juízo permutas e aquisições, com fins de utilidade pública." (Seabra,1987:130)

Já o processo de canalização do rio Pinheiros teve por objetivo a geração de energia, necessária tanto à cidade quanto à produção industrial. A companhia teve ganhos pelo empreendimento de energia e pela expropriação das terras, já que se apropriou de toda valorização gerada pelo processo de canalização. "A Companhia mobilizou todos os proprietários da "zona de enchente" e tornou-se proprietária de 21 milhões de metros quadrados de terra. Apenas $10 \%$ das terras continuaram nas mãos de antigos proprietários, possivelmente daqueles que continuaram tendo parte de suas terras situadas abaixo da linha de enchente, após terem acordado com aquelas doações pagamento de benefício. E possivelmente, daqueles que, ao final do processo, efetuaram o pagamento do benefício em dinheiro." (Seabra,1987:244) 
Ao mesmo tempo em que o processo de canalização possibilitou a incorporação das várzeas à cidade de São Paulo, transformou profundamente a relação dos moradores da cidade com os rios: "O processo da transformação tecnológica - canalizações e drenagem foi subtraindo da vida desses habitantes qualquer significação histórica do rio e das várzeas. Produziu-se um espaço tecnológico, estranho aos habitantes da cidade. É um espaço produzido segundo uma lógica produtivista que visa incessantemente maiores rentabilidade" (Seabra,1987:108)

As áreas de rio e várzea passaram a não mais fazer parte do espaço lúdico urbano. Antigamente São Paulo possuía inúmeros campos de futebol nas áreas de várzea, e também diversos clubes mantinham atividades náuticas nos rios, sendo o rio espaço de recreação de toda população paulistana até o começo do século.

Também os rios passaram a não ser mais fonte de renda para seus habitantes, que mantiveram por muito tempo atividades produtivas, tais como a pesca, pecuária (pastagem em áreas de várzeas) e extrativismo (a extração de argila, pedregulhos e areia).

Com a canalização a relação entre rio e cidade torn-se abstrata, a de viabilizar as circulações que garantiam os meios de produção urbanos: "Não é preciso ver o rio para se relacionar com eles. Sequer é preciso atravessá-lo. Á sua existência social está na energia que é consumida, e está no preço de todas as mercadorias que circulam pela cidade. Pois, o espaço do rio e das várzeas é agora um espaço de circulação e como tal, um espaço da produção em termos gerais." (Seabra,1987:109)

\subsection{As várzeas e o sistema de drenagem}

Ao longo de todo o século $X X$ os leitos dos rios sofreram obras de retificação e canalização que desprezaram suas relações naturais e enquanto paisagem. Os rios paulistanos originalmente eram meândricos e com baixa declividade: "Tanto o Pinheiros como o Tietê circundam a cidade de São Paulo em movimentos lentos, preguiçosos, por longo e sinuoso leito repleto de meandros. Construíram, ao longo da sua própria existência, uma planície de inundação (as várzeas) bastante vasta fazendo e refazendo o seu próprio leito deixando, entre uma e outra cheia, meandros abandonados formando lagoas em semicírculos." (Seabra, 1987:12)

Na medida em que as obras foram se concretizando e a várzea foi sendo ocupada, as enchentes passaram a ocorrer periodicamente: "O combate ás inundações nos arredores da capital é o grande objetivo da Comissão na década de 20. As inundações aparecem como fenômeno histórico, num certo sentido redefinindo o significado das cheias naturais episódicas do rio e das várzeas, para constituir-se em flagelo. As cheias são um fenômeno do rio, as inundações um fenômeno social." (Seabra,1987:120)

Além da canalização dos grandes rios urbanos Tamanduateí, Pinheiros, e Tietê tivemos nas décadas de 80 e 90 o Programa de Canalização de Córregos, PROCAV 1 e 2, responsáveis por canalizar a maioria dos rios e córregos da cidade, transformando-os em avenidas de fundo de vale: "O PROCAV 1 foi um programa da Prefeitura da Cidade de São Paulo, de obras múltiplas realizadas em bacias hidrográficas do município, iniciado em $1987 \mathrm{com}$ a canalização de nove córregos, num total de 27,9 km de canais, 23,8 km de avenidas, remoção de 1.590 famílias e 995 imóveis das áreas de intervenções das obras. O PROCAV 2, iniciado em 1994, contemplou a canalização de 1 córregos distribuídos pelas zonas leste, norte e sul do município de São Paulo, totalizando $35,4 \mathrm{~km}$ de córregos canalizados, 36,6 km de vias marginais paralelas ao longo desses córregos, a construção de oito reservatórios de detenção, a remoção de 4.500 famílias, a desapropriação de cerca de novecentos imóveis das áreas de intervenção das obras, a urbanização de três favelas e a implantação de 29 praças públicas" (Brocaneli et al., 2008:152).

Com a retificação e canalização dos rios e córregos, a velocidade de escoamento das águas tende a aumentar, pois à medida que a precipitação ocorre o volume de água escoa pelos dutos e canais de drenagem diretamente para os leitos dos rios. A consequência imediata é o aumento das inundações a jusante.

A política de sistema de macrodrenagem aplicada em São Paulo foi baseada no conceito de escoar o mais rápido possível a água precipitada, esse princípio foi abandonado pelos países desenvolvidos no início da década de 1970. "Em resumo, mas sem prejuízo de precisão, a equação das enchentes da Região Metropolitana de São Paulo (extrapolável para outros centros urbanos) pode assim ser expressa e entendida: volumes crescentes maiores de água, em tempos sucessivamente menores, sendo escoados para drenagens naturais e construídas progressivamente incapazes de lhes dar vazão, tendo como palco 
uma região geológica já naturalmente caracterizada por sua dificuldade natural em dar bom e rápido escoamento às suas águas superficiais." (Santos,2017:58)

Pode-se dizer que as enchentes de São Paulo surgiram com a canalização dos rios e tornaram-se parte do contexto urbano, mas não foram só as enchentes que se tornaram um problema crônico da cidade. Outra questão advinda do processo de canalização foram os intermináveis assoreamentos dos leitos dos rios: "A questão do assoreamento dos canais em São Paulo (Tamanduateí - Tietê e Pinheiros) aparecerá sempre renovada. O volume do assoreamento tem crescido ao longo do tempo e explica-se pela urbanização das bacias. $O$ índice de impermeabilização crescente aumenta o volume do escoamento superficial; as calhas naturais recebem um volume crescente de esgotos in natura, dessa enorme área que se constituía já na Região Metropolitana de São Paulo." (Seabra,1987:135)

Outro fator histórico que contribuiu ao agravamento das enchentes em São Paulo foi a divergência com relação aos níveis de água a serem mantidos pelas represas. Enquanto que para a produção de energia era interessante manter as represas sempre cheias, para o controle das enchentes era importante mantê-las sempre vazias para que pudessem absorver o excesso de água da drenagem urbana. Nesse impasse a prioridade foi dada à produção de energia, tendo como consequência a ampliação dos problemas relativos às enchentes. "Pode-se dizer que desde a construção da Represa do Guarapiranga, no começo do século, se desencadeara um processo que integrava de modo mais ou menos definitivo a Bacia do alto Tietê à de Pinheiros mas a reversão dos curso do Pinheiros, com as usinas de recalque, e depois o alteamento das Barragem de Parnaíba, inverteram também o sentido dessa integração. Consumou-se o complexo hidrelétrico de Cubatão e definiu-se uma série de problema do escoamento superficial do Tietê na cidade de São Paulo." (Seabra,1987:251)

\subsection{As várzeas e as redes metropolitanas}

São Paulo se consolidou enquanto metrópole pela condição estratégica de sua localização: "Sabemos que sua estruturação territorial, de padrão metropolitano, é o resultado de um processo histórico cujo traço mais marcante foi a dimensão e a rapidez de sua consolidação. A urbanização que levou a cidade ao patamar de metrópole realizou-se entre a última década do século XIX e as primeiras do século XX e foi regida pela articulação de alguns importantes elementos: a sua localização geográfica em relação ao contexto regional; as características topográficas do planalto paulista; a distribuição dos seus sistemas hidrográficos e, as transformações econômicas e técnicas introduzidas gradualmente no seu sistema produtivo" (Meyer et al. 2015:13).

O seu processo de metropolização foi marcado pelo crescimento exponencial de população, rápida expansão urbana periférica, conurbação com os municípios vizinhos e conservação e manutenção de sua condição de centralidade.

O entendimento das várzeas como estruturadoras do território urbano paulistano e paulista está na compreensão destas áreas como potenciais áreas de transformação urbana na escala local e como chave de transformação intrarregional na escala metropolitana: "Não se constitui nenhum exagero afirmar que os fluxos e relações que se estabelecem à partir da Região Metropolitana de São Paulo como o resto do País, se realizam através das vias marginais expressas do Tietê e do Pinheiros. Existem, pois conexões diretas, com a Rodovia Fernão Dias que se destina a Belo Horizonte, com a Rodovia presidente Dutra através da qual liga-se São Paulo e Rio de Janeiro; conexão com todo o interior de São Paulo pelas Rodovias Bandeirantes e Rodovia Anhanguera em direção a região urbano-industrial de Campinas, com a Rodovia Castelo Branco que em direção a Alta Sorocabana alcança os Estados de Mato Grosso e Paraná; com a Rodovia Regis Bitencourt em direção a Curitiba, sendo que pela marginal Pinheiros todo o sistema se liga ao Porto de Santos." (Seabra, 1987:7).

O caráter estrutural das áreas de várzeas na metrópole de São Paulo se dá a partir do entendimento do seu papel na articulação de escalas. Enquanto a escala metropolitana é articulada pelos anéis perimetrais de circulação (o Rodoanel e o minianel configurado pela conjugação das avenidas marginais Tietê e Pinheiros, e av. dos Bandeirantes e do Estado); a escala regional é articulada pelas avenidas paralelas que apoiam as avenidas marginais e pelas transposições existentes. Já a escala local é articulada por um sistema de vias locais bastante insuficiente em termos de microacessobilidade. $O$ tamanho das glebas industriais tem um papel central nesta configuração dos sistema de vias. 


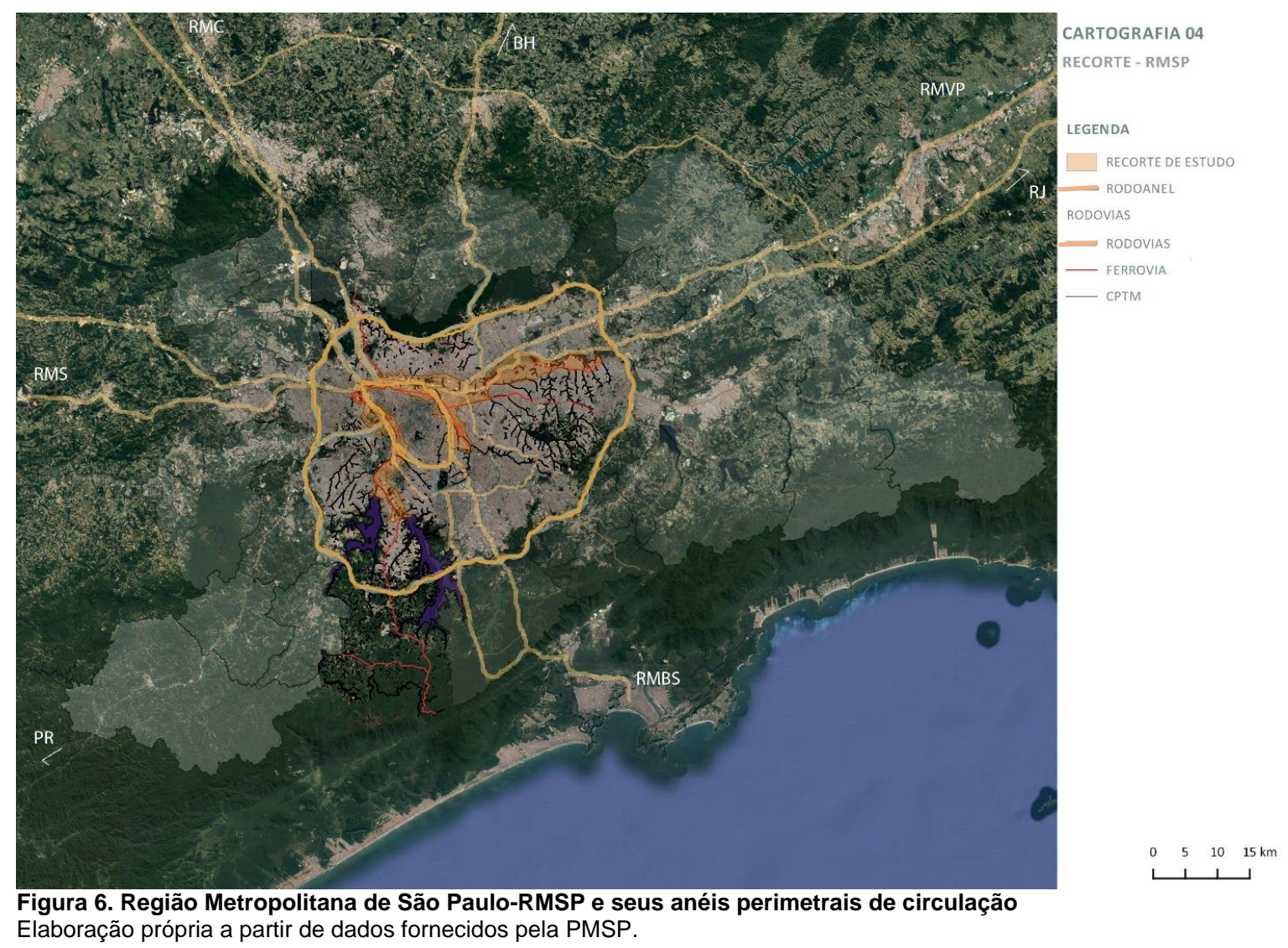

O potencial de transformação das áreas de várzea tem origem no processo histórico de consolidação da metrópole: "As planícies fluviais da Bacia de São Paulo definiram um território estratégico de estruturação metropolitana, em função da incorporação sucessiva e cumulativa de diversos sistemas técnicos ao longo da história da cidade de São Paulo. Esse território foi conformado nas dinâmicas próprias de ciclos de investimento e intervenção com características diversas quanto às estratégias espaciais e aos agentes mobilizados para sua concretização" (Franco et al., 2015:56). Tal potencial mantém-se no presente pelas possiblidades ocasionadas tanto pela sobreposição dos sistemas técnicos como pela articulação com o sistema de mobilidade e as redes de escala macrometropolitana.

Sua condição contemporânea passa pela constituição da macrometrópole paulista, marcada pela dispersão territorial e por uma urbanização extensiva (Meyer et al, 2015). "A estruturação da Macrometrópole Paulista corresponde à prevalência de um novo ciclo urbano e/ou de um novo padrão de urbanização, o qual pode ser qualificado como de urbanização dissipada, dispersa ou difusa, para fazer referência aos espaços urbano- regionais constituídos pela tendência à urbanização total do território, a partir de um padrão de expansão urbana a que se associaram novas formas de organização e de ocupação do solo. Este é resultado da ação de elementos fixos e móveis, isto é, dinâmicos. Organiza-se por meio de redes, devendo por isso ser entendido como um espaço relacional, que tem como suporte aspectos concretos do território, mas que é, porém, sujeito a permanente e dinâmica reorganização de seus aspectos móveis" (Governo do Estado de São Paulo, 2014:24).

É dentro desta perspectiva, de importante nó das redes metropolitana que configuram a Macrometrópole Paulista, que as áreas de várzea devem ser compreendidas e analisadas. 


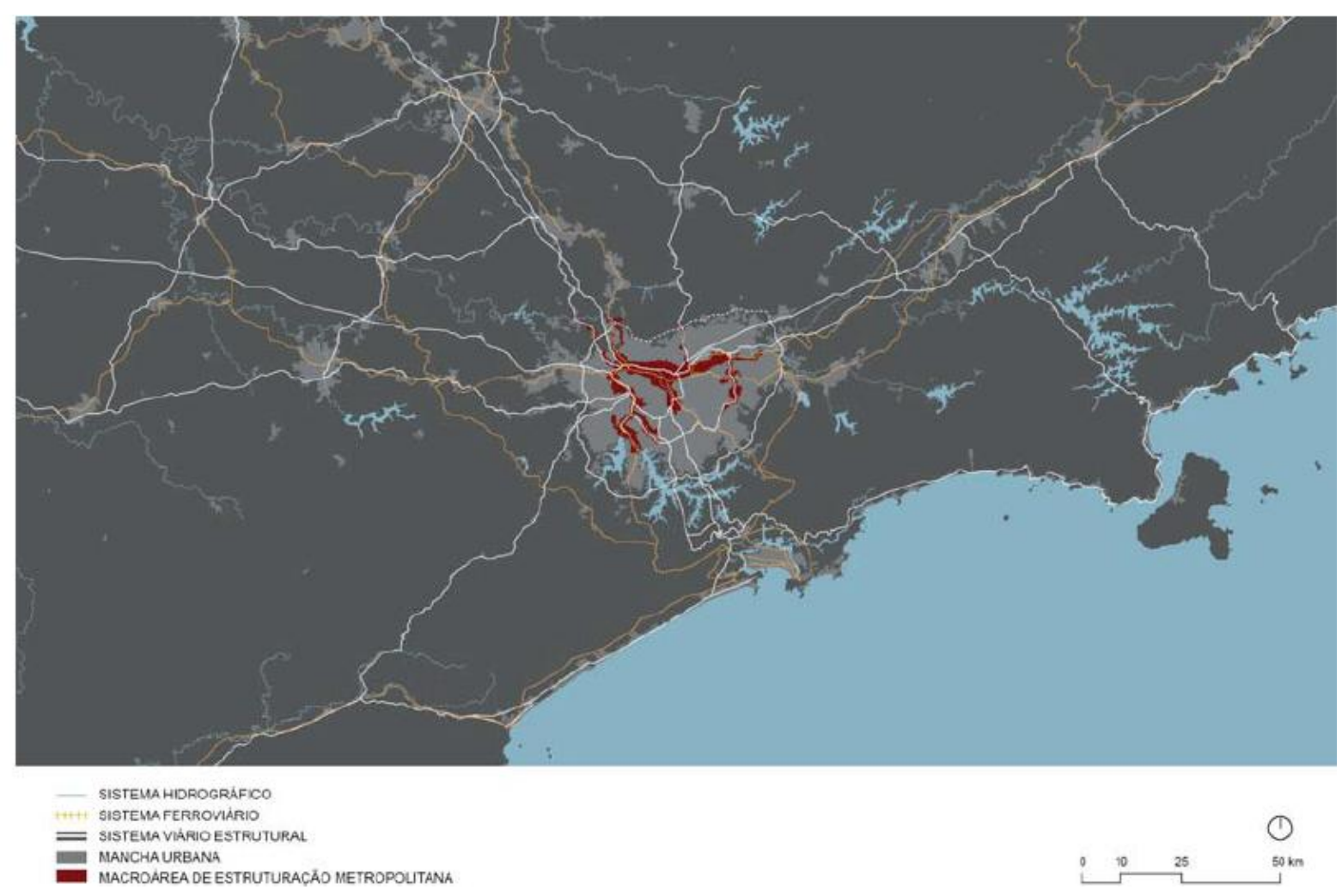

Figura 7. Inserção da Macroárea de Estruturação Metropolitana no contexto da Macrometrópole paulista Fonte: (Franco et al., 2015:62)

\section{CARACTERIZAÇÃO DAS VÁRZEAS}

Buscando informações que possam contribuir ao atual processo de caracterização das várzeas foram elaborados alguns mapas, dispostos a seguir, sobre algumas questões de interesse a essa pesquisa, tais como características ambientais (hidrografia, áreas verdes, geomorfologia), características infraestruturais (sistema de transporte) e de morfologia urbana (uso do solo, densidade demográfica e existência de glebas). A partir da organização das informações que dizem respeito às semelhanças e diferenças entre as várzeas de São Paulo podemos constatar:

Do ponto de vista ambiental as três várzeas mantém certa unidade, pois possuem a mesma formação geológica: planícies aluviais de baixa declividade formadas por bacias sedimentares. Possuindo importância fundamental enquanto infraestrutura verde na organização do sistema hídrico e de drenagem.

Com relação à infraestrutura de mobilidade o sistema sob trilhos incide de diferentes modos nestas áreas: enquanto as linhas de trens metropolitanos (CPTM) localizam-se paralelas aos rios, as linhas de metrô fazem as conexões transversais entre várzeas. Também podemos identificar uma diferença de escalas com relação ao sistema viário: enquanto na escala metropolitana as vias marginais também correm paralelas aos rios, a escala local é mantida pelas conexões transversais das transposições que costuram e conectam as duas margens.

Quanto à morfologia urbana, com relação à densidade podemos constatar que com exceção da zona leste e de alguns trechos centrais da várzea do rio Tietê, que mantém alta densidade, a maior parte das áreas de várzea apresenta uma baixa densidade demográfica.

Quanto ao uso do solo, podemos notar o uso predominantemente habitacional no trecho leste do várzea do Tietê e no trecho central da várzea do rio Pinheiros. Áreas predominantemente comerciais aparecem próximas à área central da cidade e nas bordas do rio Pinheiros. Enquanto equipamentos públicos, galpões e áreas predominantemente industriais se distribuem ao longo das três várzeas.

Já com relação à existência de glebas e grandes lotes podemos notar que eles se distribuem de forma homogênea pelas três várzeas. 


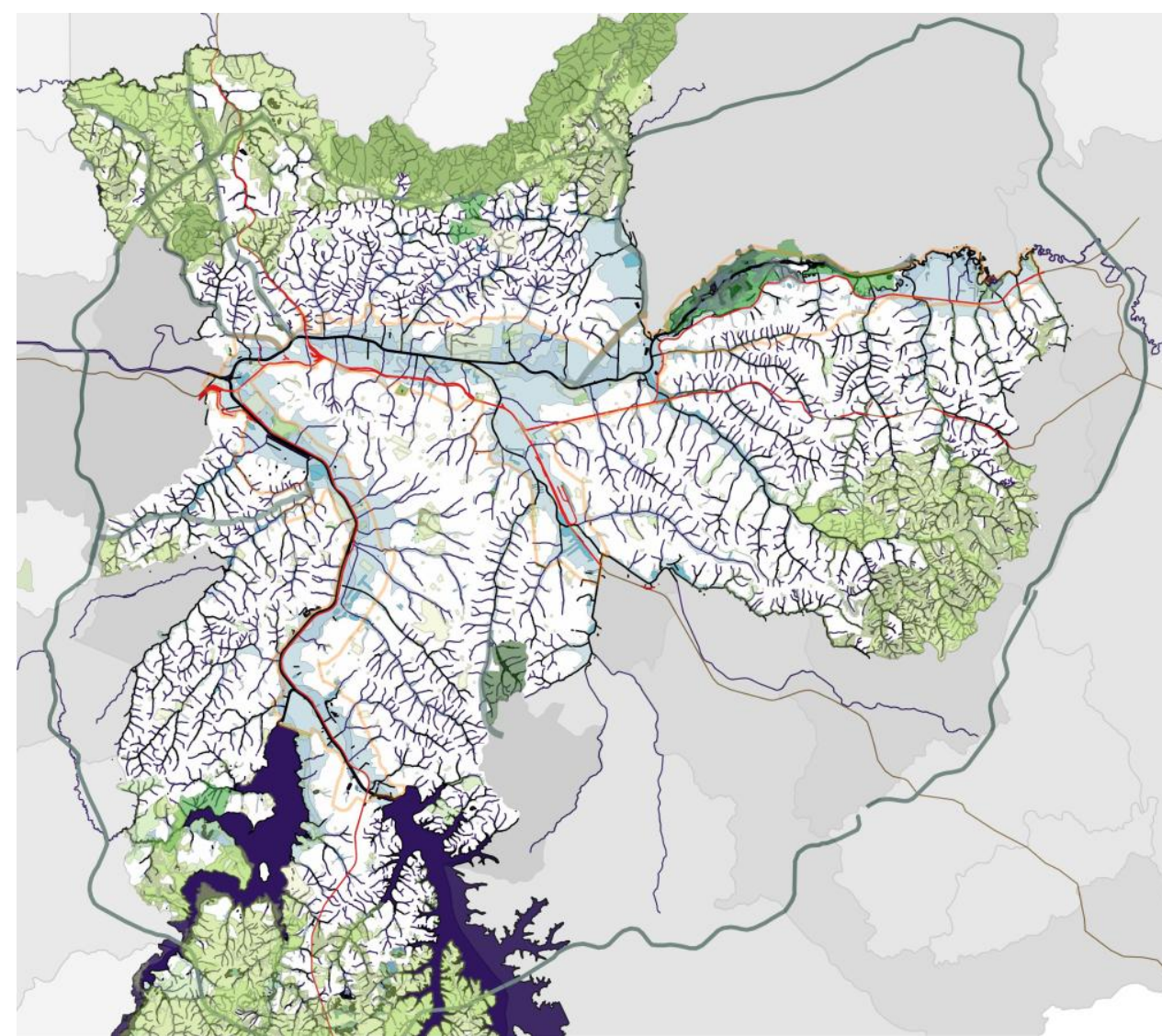

CARTOGRAFIA 11

RECORTE- AREAS VERDES

LEGENDA

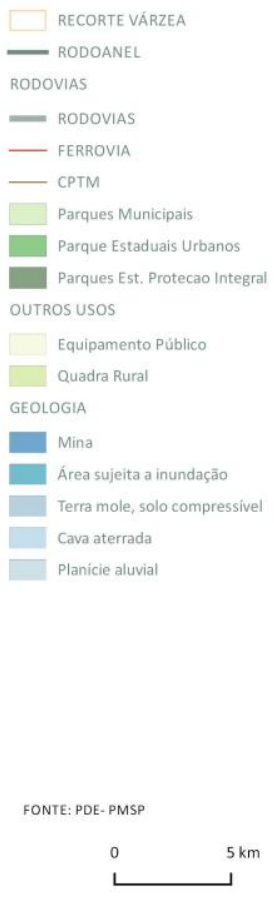

Figura 8. Sistemas ambientais das áreas de várzea Paraíba.

Elaboração própria a partir de dados fornecidos pela PMSP.

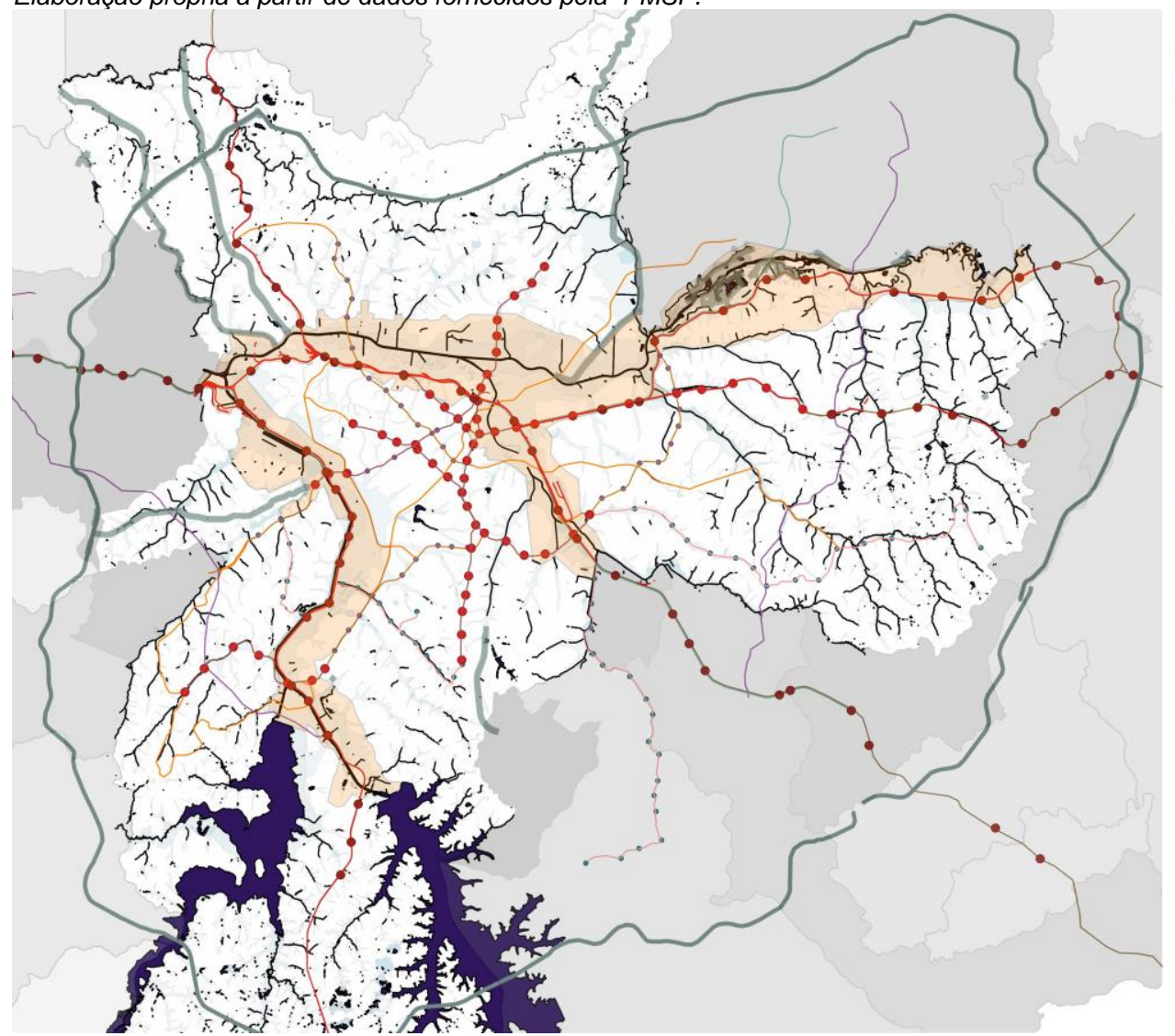

CARTOGRAFIA 13

INFRAESTRUTURA- LINHA FÉRREA

LEGENDA

RECORTE DE ESTUDO

- RODOANEL

RODOVIAS

RODOVIAS

— CPTM

- MEtrô EXISTENTE

— Metrô Planejado 2016

- Monotrilho Planejado 2016

- Metrô Planejado 2025

- Trem Planejado 2025

- Moda a ser definido 2025 (27)

- Trem Estação Existente

- Metro Estacao Existente

- Metro Estacao Planejada 2016

recorte varzea eixos viarios

FONTE: PDE. PMSP

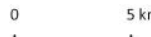

Figura 9. Sistemas de mobilidade das áreas de várzea.

Elaboração própria a partir de dados fornecidos pela PMSP 


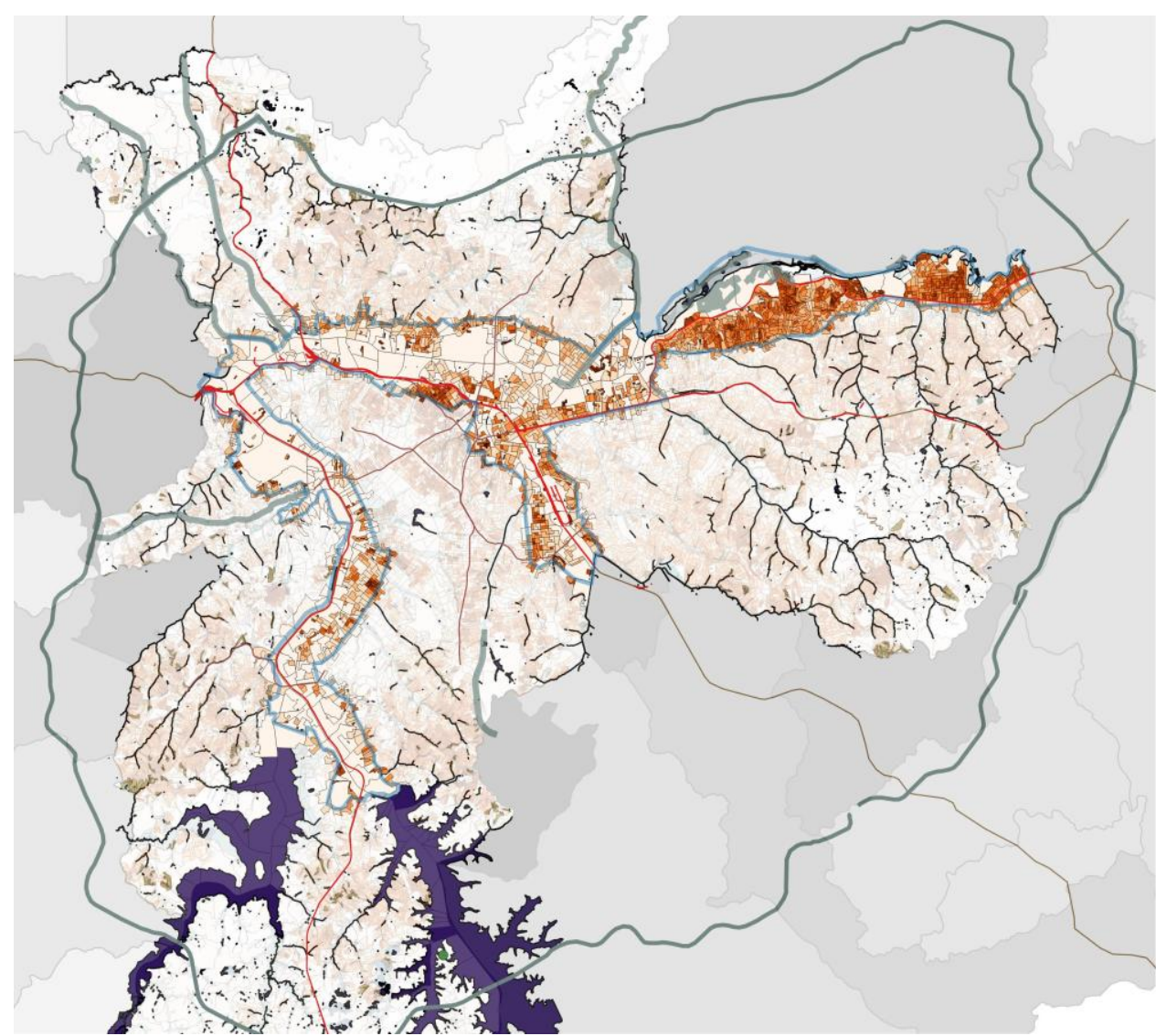

CARTOGRAFIA 16

DENSIDADE DEMOFRÁFICA

LEGENDA

RECORTE DE ESTUDO

- RODOANE

RODOVIAS

- RODOVIAS

- CPTM

- FERROVIA

SAD69_SHP_densidade_demografica_2010

$0-72$

$72-116$

$116-154$

$154-196$

196-266

$266-462$

[162-30346

FONTE: PDE. PMSP

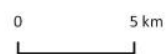

Figura 10. Densidade demográfica das áreas de várzea.

Elaboração própria a partir de dados fornecidos pela PMSP.

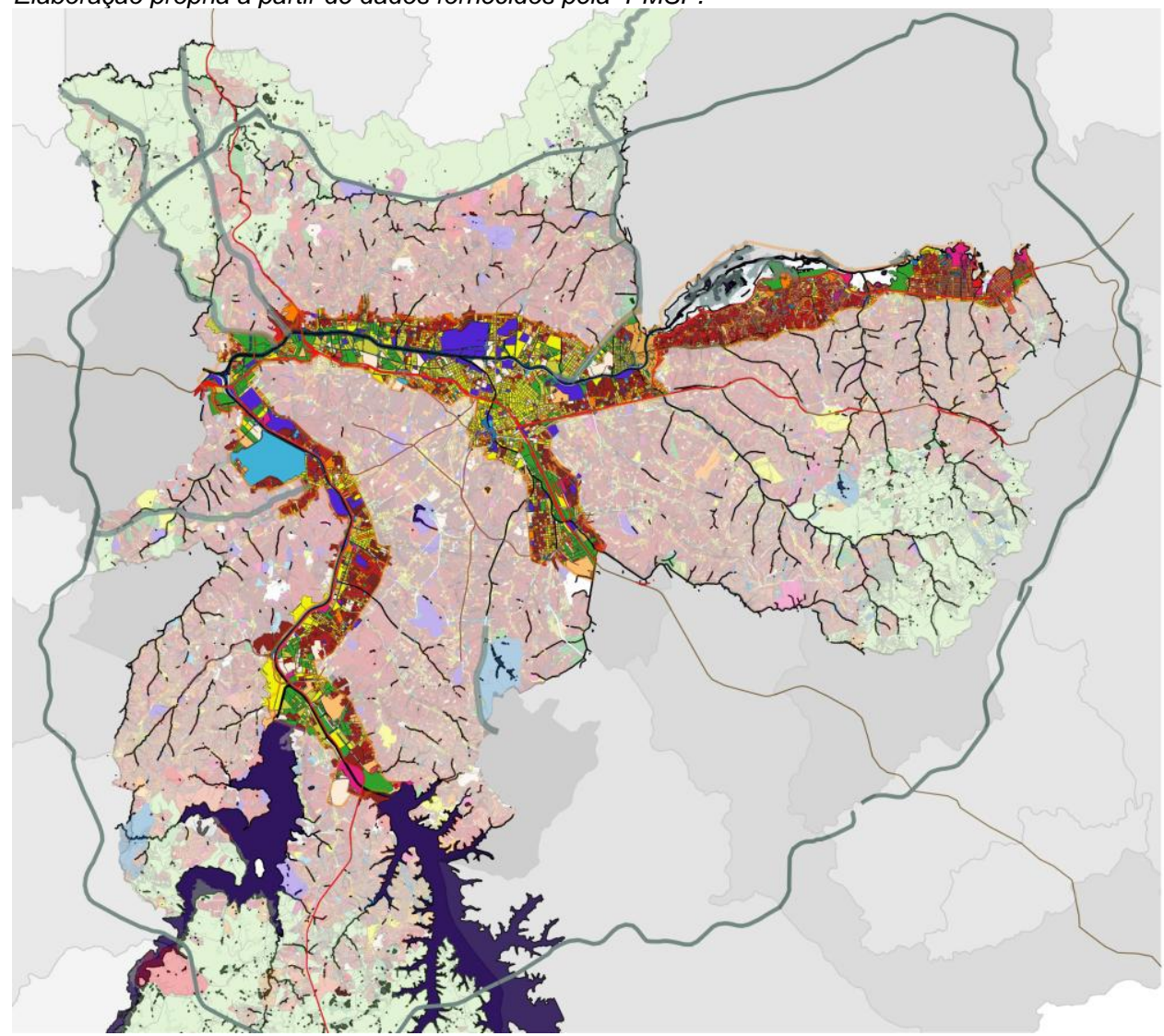

CARTOGRAFIA 17

USO DO SOLO

LEGENDA

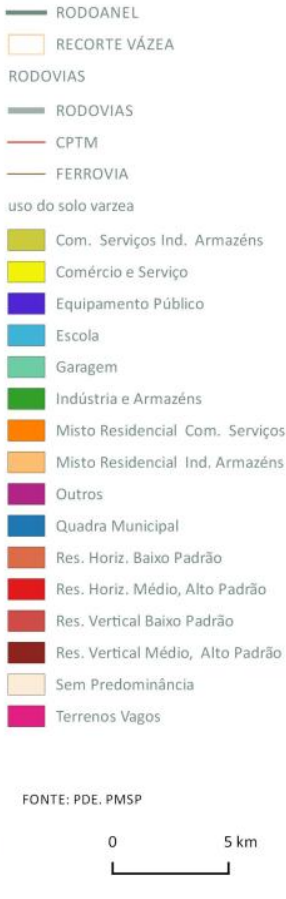

Figura 11. Uso do solo das áreas de várzea.

Elaboração própria a partir de dados fornecidos pela PMSP. 


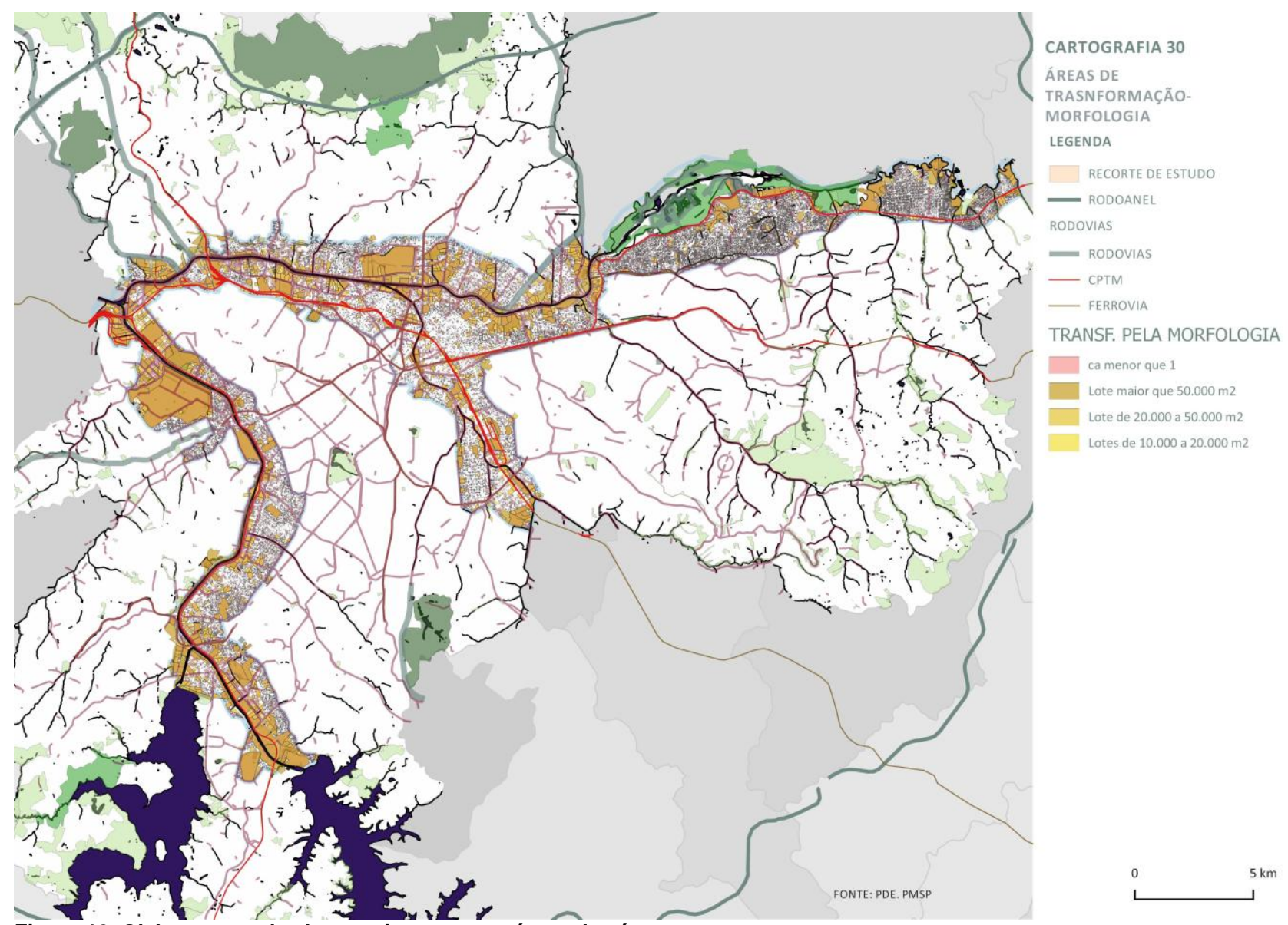

Figura 12. Glebas e grandes lotes existentes nas áreas de várzea.

Elaboração própria a partir de dados fornecidos pela PMSP.

\section{DESDOBRAMENTOS}

\subsection{Os marcos regulatórios}

As várzeas, que num primeiro momento foram fundamentais na fundação do núcleo urbano, tornaram-se essenciais como articulação estrutural entre os diversos núcleos, pois concentravam os polos de distribuição: as estações de trem e posteriormente as estações rodoviárias, que funcionavam como centralidades. Na passagem do século XX para o XXI a nova lógica de produção econômica e espacial contemporânea fez com que essas áreas se transformassem. As várzeas perderam muito de sua função de centralidade, quando as ferrovias deixaram de transportar passageiros e boa parte das indústrias existentes se deslocou na macrometrópole paulista.

Por concentrar os diversos sistemas técnicos e infraestruturas, hoje apresentam-se novamente como área estratégica de projeto e de transformação urbana na cidade contemporânea. O Plano Diretor Estratégico de São Paulo define que a zona de Macro Estruturação Metropolitana é onde deverão ser concentrados projetos e planos para o desenvolvimento da cidade. Deverão agir sobre ela instrumentos de transformação urbana, como as Operações Urbanas Consorciadas - OUCs e os Projetos de Intervenção Urbana- PIUs.

Além do reconhecimento da várzea como zona estruturante da cidade e da metrópole o Plano Diretor Estratégico de São Paulo também prevê o intenso adensamento da área. O adensamento é previsto tanto por meio dos PIUs (Projeto de Intervenção urbana) e OUCs (Operações Urbanas Consorciadas), quanto pela política de adensamento prevista ao longo dos eixos de transporte. O novo PDE definiu que o coeficiente de aproveitamento básico de toda a cidade é igual a um com exceção dos PIUs e OUCs, que devem ter o coeficiente de aproveitamento defino em plano específico; e dos eixos de adensamento de transporte, que num raio de 250 metros dos corredores de ônibus e 400 metros das estações de trem e metrô devem ter um coeficiente de aproveitamento igual a quatro. 
Outro elemento responsável pela revalorização da várzea é o sistema de transporte. Com a volta da utilização do trem para o transporte de passageiros, que desde 1992 passou a ser operado pela CPTMCompanhia Paulista de Trens Metropolitanos, a cidade passou a contar com $270 \mathrm{~km}$ de trem urbano e 91 novas estações. Novas linhas de metrô que cruzam a várzea também estão previstas no Plano de Mobilidade de São Paulo (2015), o que faz com que a várzea passe a operar com uma sobreposição de modais de transporte: metrô, trem urbano, corredores de ônibus, vias expressas, vias arteriais e ciclovias.

Acredita-se que os encaminhamentos das diretrizes do PDE podem não apenas reforçar o processo de revalorização das áreas de várzea, que já está em andamento, como também podem abrir caminhos para novas frentes urbanas: a construção da paisagem de uma nova Orla Fluvial Urbana, com um sistema de espaço público associado ao sistema de mobilidade urbana: "O PDE reconhece o papel do Município no contexto regional, identificando um território estratégico para a estruturação das dinâmicas metropolitanas de São Paulo ao longo das margens dos seus principais rios - Tietê, Pinheiros e Tamanduateí - e da orla ferroviária, que concentra atividades econômicas e espaços produtivos em processo de transformação. Estas áreas deverão ser objeto de projetos urbanos que orientem propostas de alteração do padrão de urbanização para equilibrar a distribuição de moradia e emprego, renovar os usos do seu parque fabril, integrar a cidade com seus rios - almejando, assim, melhores condições de vida urbana" (PMSP, 2014:10).

\subsection{A questão ambiental}

Recentemente o rio e suas margens, frentes e várzeas voltam a serem temas de discussão e de disputa do espaço urbano. Da visão sanitarista ligada a engenharia que dominou o planejamento urbano na virada do século XX, passando pela visão rodoviarista da década de 50, onde os leitos dos rios cederam espaços ao sistema viário, hoje a questão das águas urbanas é reavaliada.

É fundamental que no processo de reocupação das áreas de várzeas da cidade de São Paulo sua função ambiental possa ser recuperada enquanto ecossistema urbano, principalmente no que diz respeito à sua inserção na paisagem da cidade. "Parece ser de grande importância o ressurgimento da água na paisagem paulistana, não somente como atenuante das cheias, mas também como elemento de integração na relação homem $\mathrm{x}$ natureza. A exposição das águas na paisagem da cidade e seu reconhecimento é uma necessidade tanto urbana e paisagística quanto ecossistêmica, pois o equilíbrio ambiental no espaço da cidade é um dos fatores para o desenvolvimento das cidades sustentáveis" (Brocaneli et al., 2008:154).

A questão ambiental da várzea passa necessariamente pela discussão da potencialidade da sua configuração como infraestrutura verde, pela sua função tanto como corredor ecológico como o seu papel na drenagem urbana. A equação da drenagem urbana, mobilidade e reconstituição da paisagem da orla é uma questão de extrema importância.

\subsection{Questão simbólica}

Além da questão ambiental aparece também a questão simbólica, na medida em que as marginais se consolidam como porta de entrada adquirem importância enquanto símbolo dessas novas centralidades que se começam a se delinear na Orla Fluvial Urbana. Entende-se por Orla Fluvial Urbana a área localizada em área urbana, composta pela margem imediata de rios, canais e lagos (incluindo faixa de construção/manutenção dos canais e lagos) e pelas áreas adjacentes a esta; formada por calçadas, vias, jardins e parques; correspondentes ao seu entorno imediato.

No processo de apropriação das várzeas pelo tecido urbano houve perda da sua importância como espaço real: "Enquanto os rios e as várzeas são tangíveis, reais, concretos e como tal existiam na prática da vida têm-se deles uma percepção sensorial imediata, desenvolvem-se relações diretas por vezes, até afetivas. Mas o curso das transformações da sua existência natural levaria necessariamente também a uma existência abstrata, não tangível... Os rios e as várzeas acabariam por serem transformados num espaço tecnológico. Nestas condições a representação possível será pensada, teórica, programada. Os habitantes da cidade já não dão conta da sua existência. Não deixam de ser curadas as reações que ocorrem diante de algumas imagens do Tietê ou do Pinheiros... O habitante de São Paulo descobre-os naqueles curtos instantes e perde-os em seguida. $\mathrm{Na}$ cidade os canais do Pinheiros e do Tietê, como traços retilíneos orlados por um sistema de vias expressas, onde dominam movimentos rápidos sincronicos, aparecem à distância como cenário de um balé bem regulado." (Seabra,1987:66). Portanto processos, projetos e planos devem levar em consideração a importância de se recuperar a várzea enquanto espaço real e simbólico da cidade. 


\section{4 Áreas de transformação}

As várzeas permanecem, ainda hoje, com glebas, áreas de baixa densidade demográfica e construtiva e ausência de infraestruturas e microacessibilidade. Apesar da sua urbanificação deficiente, estas áreas hoje se oferecem como áreas de transformação da cidade, pois nelas estão concentrados os grandes vazios urbanos: "A ocorrência dos vazios urbanos não é um problema recente. A perda de funções de determinadas parcelas da cidade ocorre toda vez em que há um desequilíbrio ou um 'descompasso' entre o espaço construído e seus usos, ou seja, partindo-se do pressuposto que uma edificação ou conjunto de edificações possui determinadas características que justificam sua utilização ao se modificarem as atividades ali exercidas ela perde sua função original e via de regra é abandonada" (Nunes, 2004:65).

Áreas com potencial de transformação distribuídas ao longo da várzea configuram espaços de intermediação. "(...) trata-se de terrenos vastos que oferecem um potencial de reciclagem para múltiplos usos. Cada vez mais, o rio é percebido como lugar atrativo que dá uma identidade específica à cidade, causando uma valorização progressiva das margens urbanas dos rios através de diversas funções" (Coy, 2003:6).

Estas áreas apresentam-se como oportunidades para a realização de projetos urbanos integrados em escala territorial, pois os vazios urbanos ao longo de rios repetem-se ao longo de imensas áreas de várzea, conectando diversas cidades e territórios. Tais projetos têm a potencialidade de se apresentar como reestruturadores das cidades e das relações estabelecidas, e como elemento integrador e desfragmentador do território ocupado pelo sistema de redes, capaz de lidar com a nova lógica do sistema de organização do território e da cidade contemporânea, a lógica das redes e dos fluxos.

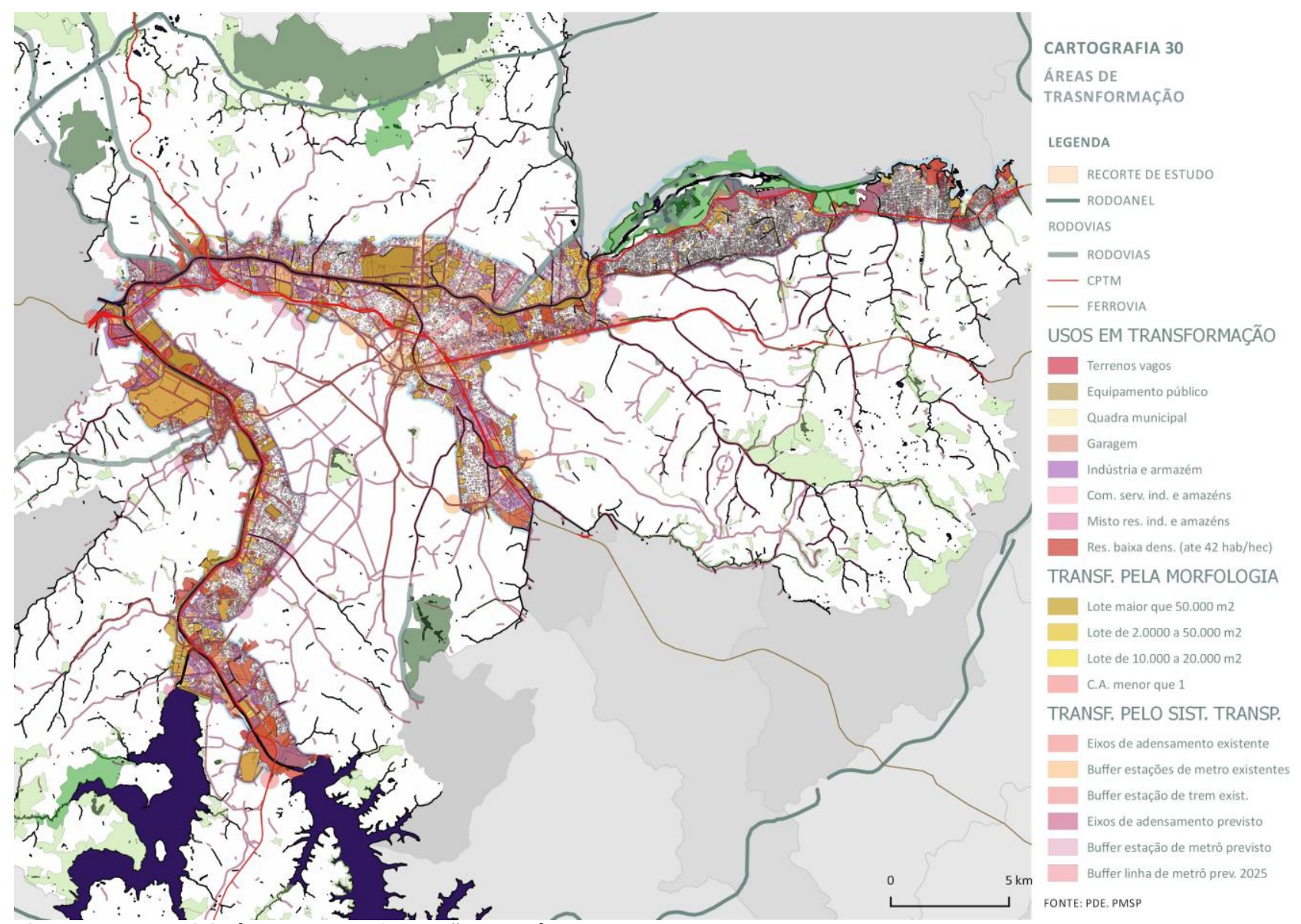

Figura 13. Potenciais áreas de transformação nas várzeas.

Elaboração própria a partir de dados fornecidos pela PMSP.

A partir da pesquisa do processo histórico e atual de transformação das áreas de várzeas acredita-se ser possível discutir os atuais encaminhamentos e problematizar os novos processos de ocupação destas áreas. 


\section{BIBLIOGRAFIA}

AB'SABER, A. N. (2007). Geomorfologia do sítio urbano de São Paulo. São Paulo: Atêlie Editorial.

BROCANELI, P. F. \& Stuermer, M. M. (2008). Renaturalização de rios e córregos no município de São Paulo. Revista Exacta (São Paulo), vol.6, n1. p. 147-156. Jan./jun.2008. Recuperado de: https://www4.uninove.br/ojs/index.php/exacta/article/view/799 (Consulta: 16/01/2017).

COY, M. (2003). A interação rio-cidade e a revitalização urbana. Experiências europeias e perspectivas para a América Latina. Revista Franco Brasileira de Geografia (São Paulo),18. Recuperado de: https://confins.revues.org/8384\#entries (Consulta: 29/11/2016).

EIGENHEER, D. M. (2011) Mobilidade e dispersão metropolitana: Sistema Anhanguera Bandeirantes. (Dissertação de Mestrado, Faculdade de Arquitetura e Urbanismo São Paulo, Universidade Presbiteriana Mackenzie). Recuperado de http://www.scielo.org/php/index.php.

FRANCO, F. de M. (2005). A Construção do Caminho: A Estruturação da Metrópole pela Conformação Técnica das Várzeas e Planícies Fluviais da Bacia de São Paulo. (Tese de Doutorado, Faculdade de Arquitetura e Urbanismo, Universidade de São Paulo). Recuperado de http://www.teses.usp.br/.

FRANCO, F. de M., D'Almeida, C. H. \& Abreu G. K. M. A (2015). Macroárea de Estruturação Metropolitana de São Paulo: O projeto urbano como instrumento de transformação do território. Revista Iberoamericana de Urbanismo (Buenos Aires), 12, 53-74.

GORSKI, M. C. B. (2010). Rios e Cidades. Ruptura e reconciliação. São Paulo: Editora Senac.

KAHTOUNI, S. (2004). Cidade das águas. São Paulo: RIMa Editora, 2004.

MEYER, R. M. P., Grostein M. D. \& Biderman, C. (2004). São Paulo Metrópole. São Paulo: Editora da Universidade de São Paulo, Imprensa Oficial do Estado de São Paulo.

MEYER, R. M. P., Galvão, R. F. P. \& Longo, M. R. (2015). São Paulo e suas escalas de urbanização: Cidade, metrópole e macrometrópole. Revista Iberoamericana de Urbanismo (Buenos Aires), 12, 7-32.

NORDENSON, G., Seavitt, C. \& Yarinsky, A. (2010). On the water- paralisade bay. New York: Moma Ed.

NUNES. M. B. (2004). A configuração espacial do Tietê: a região da Água Branca e as áreas municipais. (Dissertação de mestrado, Faculdade de Arquitetura e Urbanismo, Universidade de São Paulo). Recuperado de http://www.teses.usp.br/.

PEREZ, J. Z. B. (2003). Urbanismo nas várzeas existentes: Da região dos rios Tietê e Pinheiros ao território das desapropriações. (Tese de doutorado, Faculdade de Arquitetura e Urbanismo, Universidade de São Paulo). Recuperado de http://www.teses.usp.br/.

SALES, M. M. L. (2008). Territórios de intermediação: Uma hipótese para a análise e o projeto da cidade Contemporânea. (Tese de Doutorado, Faculdade de Arquitetura e Urbanismo, Universidade de São Paulo). Recuperado de http://www.teses.usp.br/.

SANTOS, A. L. (2014). Paisagem útil: o Rio Tietê e a urbanização paulistana (1966 - 1986). (Dissertação de Mestrado, Faculdade de Arquitetura e Urbanismo, Universidade de São Paulo). Recuperado de http://www.teses.usp.br/.

SANTOS, A. R. dos (2017). Cidades e Geologia: discussão técnica e proposições de projeto de lei de grande interesse para as populações urbanas. São Paulo: Editora Rudder.

SEABRA, O.C. de L. (1987). Os meandros dos rios nos meandros do poder: o processo de valorização dos rios e das várzeas do Tietê e do Pinheiros na cidade de São Paulo. (Tese de Doutorado, Faculdade de Filosofia, Letras e Ciências Humanas, Universidade de São Paulo).

SEABRA, O. C. de L. (2015). Urbanização e industrialização: rios de São Paulo. Revista Labor \& Engenho, (Campinas), v.9, n 1, p 37-48, jan./mar.2015. Recuperado de: www.conpadre.org , (Consulta: 17/01/2017)

SECCHI, B. (2006). O Projeto da Cidade Contemporânea In Primeira lição de urbanismo. (P. M. R. Sales, \& M. Barda Trad.). São Paulo: Ed. Perspectiva.

URBEM (2016). Arco Tietê. (Relatório Técnico não publicado - RT). São Paulo, SP: PMSP.

\section{Fontes eletrônicas:}

GOVERNO DO ESTADO DE SÃO PAULO, EMPLASA. (2014) Plano de Ação da Macrometrópole Paulista, 2013-2040: política de desenvolvimento da Macrometrópole, volume 1. São Paulo, SP: EMPLASA. emplasa.sp.gov.br/Cms_Data/Sites/Emplasa/Files/.../pam14_livro1_politica_web.pdf (Consulta: 10/11/2015)

Lei Municipal $n^{\circ}$ 16.050, de 31 de julho de 2014 (2014). Aprova a Política de Desenvolvimento Urbano e o Plano Diretor Estratégico do Município de São Paulo e revoga a Lei № 13.430/2002. São Paulo, SP: PMSP.

http://www.prefeitura.sp.gov.br/cidade/secretarias/desenvolvimento_urbano/legislacao/plano_diretor/ind ex.php?p=201105 (Consulta: 15/06/2016). 
Lei Municipal no 16.402/16, de 14 de março de 2016 (2016). Disciplina o parcelamento, o uso e a ocupação do solo no Município de São Paulo, de acordo com a Lei no 16.050, de 31 de julho de 2014 - Plano Diretor Estratégico (PDE). São Paulo, SP: PMSP. http://www.prefeitura.sp.gov.br/cidade/secretarias /desenvolvimento_urbano/legislacao/zoneamento/index.php?p=214281 (Consulta: 15/06/2016).

PREFEITURA MUNICIPAL DE SÃO PAULO, SECRETARIA MUNICIPAL DE PLANEJAMENTO URBANO. (2013). Arco Tietê. Chamamento Púbico no 01/2013/SMDU. (Relatório Técnico, RT). São Paulo, SP: Autor.

http://www.prefeitura.sp.gov.br/cidade/secretarias/desenvolvimento_urbano/arco_do_futuro/arco_tiete/i ndex.php?p=201110 (Consulta: 15/06/2016).

PREFEITURA MUNICIPAL DE SÃO PAULO. SECRETARIA MUNICIPAL DE PLANEJAMENTO URBANO. (2016). Projeto de Intervenção Urbana do Arco Tietê: PIU-ACT. São Paulo, SP: Autor. http://gestaourbana.prefeitura.sp.gov.br/arco-do-futuro/arco-tiete/projeto-de-intervencao-urbana-doarco-tiete/ (Consulta: 02/12/2016).

UNIVERSIDADE DE SÃO PAULO. FACULDADE DE ARQUITETURA E URBANISMO. GRUPO METROPOLE FLUVIAL (2011). Articulação Arquitetônica e Urbanística do Estudo de pré Viabilidade Técnica. Econômica e ambiental do Hidroanel Metropolitano de São Paulo. (Relatório Técnico, RT). São Paulo, SP: FAU-USP. www.metropolefluvial.fau.usp.br (Consulta: 10/06/2016). 